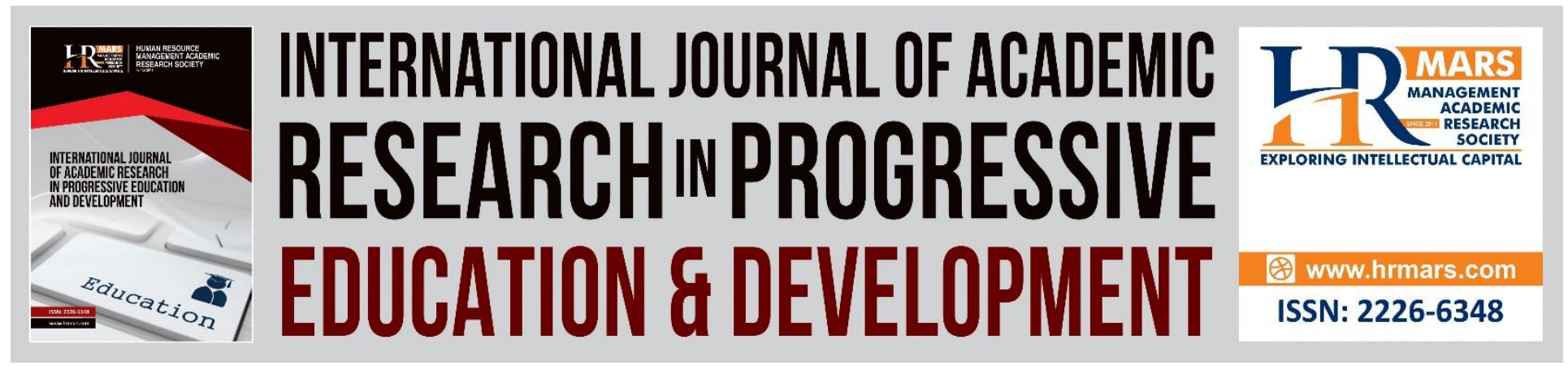

\title{
Factors Influencing Orang Asli Students' Intention to Study at A Higher Educational Institution in Malaysia
}

\author{
Mazlina Mahdzar, Muhamad Khalil Omar, Aini Jaapar, Wan Zuraida Wan \\ Mohd Zaini
}

To Link this Article: http://dx.doi.org/10.6007/IJARPED/v10-i2/9579

DOI:10.6007/IJARPED/v10-i2/9579

Received: 06 February 2021, Revised: 01 March 2021, Accepted: 30 March 2021

Published Online: 26 April 2021

In-Text Citation: (Mahdzar et al., 2021)

To Cite this Article: Mahdzar, M., Omar, M. K., Jaapar, A., \& Zaini, W. Z. W. M. (2021). Factors Influencing Orang Asli Students' Intention to Study at A Higher Educational Institution in Malaysia. International Journal of Academic Research in Progressive Education and Development, 10(2), 233-244.

Copyright: (C) 2021 The Author(s)

Published by Human Resource Management Academic Research Society (www.hrmars.com)

This article is published under the Creative Commons Attribution (CC BY 4.0) license. Anyone may reproduce, distribute, translate and create derivative works of this article (for both commercial and non-commercial purposes), subject to full attribution to the original publication and authors. The full terms of this license may be seen at: http://creativecommons.org/licences/by/4.0/legalcode

Vol. 10(2) 2021, Pg. 233 - 244

http://hrmars.com/index.php/pages/detail/IJARPED

JOURNAL HOMEPAGE

Full Terms \& Conditions of access and use can be found at http://hrmars.com/index.php/pages/detail/publication-ethics 


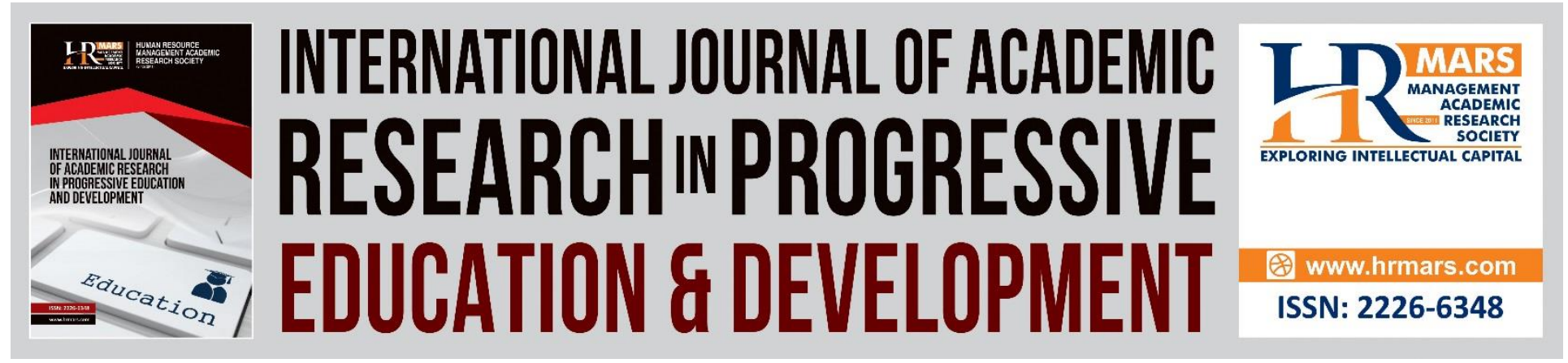

\title{
Factors Influencing Orang Asli Students' Intention to Study at A Higher Educational Institution in Malaysia
}

\author{
Mazlina Mahdzar, Muhamad Khalil Omar, Aini Jaapar, Wan \\ Zuraida Wan Mohd Zaini
}

Faculty of Hotel and Tourism Management, Faculty of Business and Management, Faculty of Architecture, Planning and Surveying, Faculty of Plantation and Agrotechnology,

Universiti Teknologi MARA, Malaysia

\begin{abstract}
The increasing competition in higher education environments have made it necessary for institutions to persuade students in recruitment market niches. Accordingly, the Malaysian higher education sector has considered several changes over the past years intending to introduce accountability for their services as well as responsibility in helping students to master and gain knowledge. The aim of this study is to identify the main factors that influence the intention to study at Malaysian public university among Orang Asli students. A total of 188 Orang Asli students were selected as the samples and a survey consisting of 17 statements was developed. Discussions were conducted using descriptive analysis method as well as independent sample t-tests. The results revealed six factors that significantly influence the decision-making of Orang Asli students in choosing which institution of higher learning to attend. They are cost of education, degree (content and structure), physical aspects, facilities and resources, the value of education, and course and career information; regarded significant impact on the students' choice. These findings will be beneficial in the decision-making process of the students and the outcomes play an important role in assisting public university marketers to plan and improve their marketing strategy, particularly concerning students recruitment.

Keywords: Education, Higher Education, Marketing Strategy, Recruitment of Students, Orang Asli, Malaysia

\section{Introduction}

In the context of higher education in Malaysia, a noticeable trend of increasing competition can be observed among universities and higher education institutes in attracting both local and international students. In other words, competitive pressure has forced higher educational institutions to identify more competitive marketing strategies in their respective recruitment markets for students recruitment purposes. Accordingly, this indicates the importance of
\end{abstract}


exploring the attributes that affect students' intention to study at a university. Overall, this is pertinent in the planning of marketing strategy for students recruitment at higher educational institutions.

In general, students in the current era have become more discerning customers considering that they tend to demand better value for their money and more selective in choosing an educational institution. As a result, these changes have called for educational institutions to generate and conduct customer analysis by examining three main aspects, namely customer segmentation, motivations, and unmet needs. According to Griffin and Hauser (1993) and Piróg (2017), the generated information gathered can provide insights into the assets and skills needed to compete, thus forming the bases of sustainable competitive advantages. The majority of the research on choice criteria in selecting a university has been conducted in the US, New Zealand, and Indonesia; for example, a study by Joseph and Joseph (1998). Nevertheless, a considerable amount of studies have been conducted to identify the factors affecting students' intention in choosing higher learning institutions. Regarding this matter, a few factors including location, cost, academic programs, advertising efforts, career prospects, and parents' influences are deemed capable of influencing individuals' choice in choosing their preferred institution. (Cubillo et al., 2006; Keskinen et al., 2008; Tucciarone, 2008; Daily et al., 2010; Ivy, 2010; Johnston, 2010; Rumana, 2019). However, a search of the literature revealed that only a few studies were conducted on different culture sample. Taking the above into consideration, the current research focuses on identifying the important factors that are commonly considered by Orang Asli students when choosing an educational institution to further their study at a tertiary level. Regarding this matter, it is necessary to understand the background of Orang Asli or indigenous people of Malaysia whereby they are generally described as ethnic minorities that possess unique languages, knowledge systems, and beliefs. Meanwhile, it should be noted that indigenous peoples often have much in common with other neglected segments of societies; for example, lack of political representation and participation, economic marginalisation and poverty, lack of access to social services, and discrimination. Thus, it is necessary to increase their access to quality education as they do not get the same opportunities as compared to the children from more well-to-do families. Biases in quality of life can be avoided and poverty can be helped through the support of a fair and quality education (Ashta et al., 2009).

\section{Literature Review}

A variety of theoretical models have been suggested to describe the factors that influence students' intention to further their study at a specific university. Specifically, each of these theoretical models provides a detailed description of the various processes involved in selecting a college among high school students. Chapman (1981) explains three models, namely economic, sociological, and combined models that describe the conceptual approaches concerning the college choice process and factors which guide students in the selection of their preferred college. According to Hossler, Schmit, and Vesper (1999), the economic model emphasises the rational decision-making process of students and their families as well as the variety of ways in which students tend to rate and utilise college attributes in making their final university choice. On a similar note, a considerable amount of research suggested that individuals will select a particular higher education institution if the benefits of attending the institution outweigh the 
perceived benefits of attending other higher learning institutions or a non-university alternative. For example, Murphy (1981) recognised academic reputation and cost as the determinants of university choice. Meanwhile, Joseph and Joseph (1998) managed to identify four most important factors in choosing an academic and educational institution and programme issues, cost of education, location and recreation facilities, and peer and family influences. Ciriaci and Muscio (2011) agreed with the importance of academic reputation as they further argued that research quality has a positive effect on students' employability. On another note, Kusumawati et al. (2010) suggest the reputation of an institution as the most significant factor in influencing students' decision to further their study. Meanwhile, the cost factor is another basic consideration among students, particularly concerning the various effect of fees. A study by Gibbons and Vignoles (2009) asserts that students from lower socio-economic backgrounds tend to have a lower attendance rate of high-quality institutions. A possible explanation for this matter is the location of these universities which are usually situated far from their home which can lead to increased costs. Furthermore, the costs related to commuting and re-location are important choice factors among lower income students which commonly prevent them from enrolling into university.

Jackson (1982) explains the second model related to the sociological aspect which specifies a variety of social and individual factors that affect students' occupational and educational aspirations. For example, the model focuses on the identification and interrelationship of factors as the indicators of enrolment in higher learning institution which include the influence of parental encouragement of significant others as well as academic performance (Sewell \& Shah, 1978; Chapman, 1984). The vast majority of researchers including Maguire and Lay (1981), Seneca and Taussig (1987), and Tierney (1983) named social activities factors such as physical appearance and social life as important attributes commonly considered by students in selecting an educational institution. In addition, familial groups such as parents and relatives, followed by those with influential significance such as teachers tend to have an impact on the selection of educational institution along with the elements affecting choice mentioned above (Oosterbeek et al., 1992; Hossler et al., 1999)

The third model which is known as the combined model utilises the most powerful indicators in the decision-making process from the economic and social models. Hossler (1985) states that this model provides a conceptual framework that predicts the effects of policy-making interventions. Regarding this matter, a few established combination models have investigated the factors that determine students' intentions to study at a higher education institution (Krone et al., 1983; Webb, 1993; Joseph \& Joseph, 1998). In particular, this seems to point towards a wide range of choice criteria including several factors such as programme-related issues; for example. the introduction of a special programme, flexibility, and length of the programme. Meanwhile, the literature further revealed other categories that can be categorised into determinant dimensions of choice such as facilities or infrastructure, accommodation, library, laboratory, cafeteria, and student union buildings. In addition, another category that should be considered is the element of academic staff such as teaching quality, staff qualification, medium of instruction, reputation, and institutional image (Tang, Tang \& Tang, 2004). Overall, reputation and cost-related issues are becoming important criteria which are commonly considered in the selection of university among students. 
The rapid development in public institutions has intensified the competitive condition in the higher education sector. As a result, one of the important strategies for public higher learning institutions to survive in the business is by gaining a greater number of students. Hence, public institutions need to help their country by transforming itself into a recognised higher education hub of excellent. Meanwhile, in terms of the programs offered, a few public educational institutions are expected to provide pre-diploma programs as an 'entry point' for individuals especially the high school leavers in fulfilling the increasing higher education demand. In line with this, Universiti Teknologi MARA through its corporate social responsibility initiative are committed to produce workforce, which leads to an increase in productivity, which pushes the country's production function outwards leading to economic growth. Overall, it is necessary to understand the factors that influence students' choice in selecting their preferred higher learning institution, especially for the indigenous ethnic group of Orang Asli, and also motivates them to further their studies in higher learning institutions.

\section{Methodology}

The sample of the present study consisted of Orang Asli students who are currently attending Malaysian secondary schools as Form Five students, followed by students who have just graduated from their secondary school within five years. The purpose of selecting these two groups was based on the highest possibility that they will continue their study at a university. In the case of the present study, their intention to study at a public university specifically Universiti Teknologi MARA (UiTM) has to be determined. Regarding this matter, it is important to note that UiTM has a special programme called Program Pra Pendidikan Tinggi (formerly known as Mengubah Destini Anak Bangsa) as one of their corporate social responsibility initiatives in helping and providing a second chance to underprivileged Malays including Orang Asli students to enrol into institutions of higher learning through the pre-diploma and diploma courses. The objective of this programme is to allow youth from the lower income group ethnic of Malays, Sarawak origin descendant, Sabah origin descendant and Orang Asli whom are underqualified to general entry requirement to be able to enter the Malaysian public university. As for basic requirements, this program accepts Sijil Pelajaran Malaysia (SPM) (translated as Malaysian Certificate of Education) candidates who obtained at least or minimum with 3 credits in the SPM result. Currently, the program offers two tracks, namely the Pre-Commerce and Pre-Science. In the case of the current research, the sampling processes were carried out through three selected Orang Asli higher education talk organised by the Department of Orang Asli Development and school carnivals. In particular, the study was conducted in a non-contrived setting during school carnivals and education motivation talk whereby the students participated in the activities at the booth counter set-up by Pejabat Program Pra Pendidikan Tinggi (PPT) with minimum researcher interference.

The instrument used in the present study was based on published researches that investigated significant factors which affect students' selection of higher education institution. The current research adopted the importance-performance analysis model developed by Joseph and Joseph $(1998,2000)$ which was translated into Bahasa Melayu. The purpose of selecting the analysis model was based on its ability to identify the relationships between important factors influencing Orang Asli students' selection of higher education institution, followed by their 
specific intentions to further their study at UiTM, Malaysia. Specifically, a self-administered questionnaire was developed and divided into two sections: demographic (5 questions), followed by the important factors influencing respondents' intention to study at a higher education institution (17 questions). The questionnaire was distributed to a total of 188 respondents selected using the convenience sampling approach through their participation in the activities. The responses to the items were measured on a five-point Likert scale where 1 represents "Strongly Disagree" and 5 represents "Strongly Agree". The survey instrument and scale measurement were adapted from previous research (Joseph \& Joseph, 2000).

On another note, the reliability tests were carried out accordingly to determine the internal consistency of the measurable items of each variable in ensuring that the combination of ordinal data with the interval data is valid for the following part of the analyses. The Cronbach alpha value obtained in the present study was 0.90. According to Pallant (2005), The score above 0.70 is considered reliable with the current sample.

\section{Results / Findings \\ Descriptive Analysis}

The descriptive statistics of the respondents are summarised in Table 1. Out of a total of 188 usable questionnaires, $77.7 \%$ are female and $22.3 \%$ are male respondents. The respondents were all between 17- 27 years old. Most of them were students (68.6\%) and unemployed. More importantly, majority of the respondents managed to state their intentions to further their study at higher education institution (see table 1).

Table 1. Respondents gender, age, job, income level, intentions to further study

\begin{tabular}{cccc}
\hline Category & Items & Frequency & Percentage \\
\hline Gender & Male & 42 & 22.3 \\
& Female & 146 & 77.7 \\
Age & $17-27$ & 188 & 100 \\
Status & Student & 129 & 68.6 \\
& Working & 19 & 10.1 \\
Income & Not working & 40 & 21.3 \\
& Less than & 162 & 86.2 \\
& RM1000 & & 10.1 \\
& RM1001 - & 19 & 3.7 \\
RM3000 & RM3001- & 7 & \\
Intentions to further & RM4000 & & \\
study & Yes & 182 & 3.2 \\
\hline
\end{tabular}




\section{Students' perception of the factors influencing their selection of educational institution}

Table 2 presents the mean scores and standard deviations of the 17 attributes that indicated students' perception of the factors that influence their selection of a university. The mean score for all attributes was in the range of 3.76 to 4.33 . As can be observed, the students tend to consider 'cleaned and safe environment' as the most important attribute in choosing a university to further their study. Meanwhile, 'Information is given on career opportunities' and 'Specialist programs/special track' are rated as the second and third most important attributes. Next, most of the students agreed that the cost of education is an important criterion in selecting a university, particularly referring to reasonable tuition and accommodation fees. Other than that, the students also agreed that it is necessary to offer a wide range of content and structure of the degree courses, reasonable entry requirements, and special track or specialist programs. A similar agreement can be observed in their perceptions of the university's physical aspects, especially concerning its facilities and resources. The mean score for these attributes is in the range of $3.97-4.33$. In light of the attributes of the value of education, the students mostly agreed that reputable degree programs and academic value are important criteria in choosing a university. Meanwhile, further findings revealed that 'Course and Career Information' is also an important criterion commonly considered by students in choosing a university. The results shown in the table describes the agreement of most of the students regarding the information given on career opportunities $(M=4.32, S D=0.77)$, the information provided to choose an area of study $(\mathrm{M}=4.20, \mathrm{SD}=0.76)$, and peer and family influences $(M=3.76, \mathrm{SD}=0.98)$.

Table 2. Summary of the Means

\begin{tabular}{lcc}
\hline Category & Mean & SD \\
\hline Cost of Education & & 0.89 \\
Reasonable cost & 4.20 & 0.86 \\
Accommodation at reasonable cost & 4.25 & \\
Degree (content and structure) & 4.17 & 0.83 \\
Wide range of courses & 4.05 & 0.80 \\
Reasonable entry requirements & 4.30 & 0.89 \\
Specialist programmes/special track & & \\
Physical Aspects, Facilities and Resources & 4.23 & 0.83 \\
Ideal location & 4.24 & 0.84 \\
Environment conducive to learning & 4.10 & 0.88 \\
Superb recreation and other facilities & 3.97 & 0.93 \\
Good social life on campus & 4.05 & 0.80 \\
Necessary resources available & 4.33 & 0.85 \\
Clean and safe environment & 4.15 & 0.81 \\
Good faculty & & \\
Value of Education & 4.16 & 0.80 \\
Reputable degree programme & 4.20 & 0.73 \\
Academic value & & \\
Course and Career Information & 4.32 & 0.77 \\
Information given on career opportunities & 4.20 & 0.76 \\
Information provided to choose area of study & 3.76 & 0.98 \\
Peer and family influences & &
\end{tabular}


Vol. 10, No. 2, 2021, E-ISSN: 2226-6348 @ 2021 HRMARS

On another note, further analysis was conducted to determine whether the contributing factors of the respondents are related to their gender. In this case, independent samples t-test was carried out to compare the mean scores between male and female respondents. However, the comparison of the mean score between males and females (Table 3) did not reveal any significant differences except for two categories, namely the Cost of Education and Course and Career Information.

Table 3. Comparisons of Means

\begin{tabular}{lccc}
\hline Category & Male & Female & $\begin{array}{c}\mathbf{P} \\
\text { value }\end{array}$ \\
\hline Cost of Education & 4.00 & 4.29 & 0.03 \\
$\begin{array}{l}\text { Degree (Content and } \\
\text { Structure) }\end{array}$ & 4.10 & 4.20 & 0.40 \\
$\begin{array}{l}\text { Physical Aspects, } \\
\text { Facilities and Resources }\end{array}$ & 3.92 & 4.14 & 0.56 \\
$\begin{array}{l}\text { Value of Education } \\
\text { Course and Career }\end{array}$ & 4.08 & 4.18 & 0.38 \\
Information & 3.97 & 4.24 & 0.02 \\
\hline
\end{tabular}

\section{Discussion}

The overall mean score suggests that most of the respondents seemed to agree that all the attributes related to the cost of education, degree (content and structure), physical aspects, facilities and resources, the value of education and course, and career information are important factors considered by the students in selecting the best university to further their study. Therefore, it can be concluded that the outcomes of the present are consistent with past literature which has successfully proven the importance and capability of the above-mentioned factors in influencing students' choice of higher education institution (Loren \& Naltan, 2014; Cubillo et al., 2006; Ancheh et al., 2007; O'Brien et al., 2007; Wagner \& Fard, 2009; Padlee et al., 2010; Abeygunawardena, 2018; Holmegaard, et al., 2014; Vulperhorst et al., 2020; Fernandez, 2010; Sia, 2011; Jalaluddin et al., 2019; Yusuf et al., 2017; Eidimtas et al., 2014; Sidin et al., 2003; Agrey et al., 2014; Mustafa et al., 2018; Hussin et al., 2019; Ariffin et al., 2014; Sia, 2013). In addition, public universities especially UiTM is known to offer a special track to Orang Asli which allows them to further their study at the university. This CSR initiative by UiTM is one of the effective strategies that help these students to succeed in their studies as well as to provide opportunity for them to uplift their family household income in the future. On a more important note, UITM should concentrate on providing more information regarding their academic program and learning facilities during student recruitment activities as one of the means of marketing and promoting their programs to stay competitive. Meanwhile, they should also develop a prestigious institutional reputation to ensure the survival of their programs and enhance their competitiveness.

Generally, it is important to acknowledge that students nowadays are keen to register with a higher learning institution that has a good reputation based on the assumption that it will be easy for them to get employed in the future. Accordingly, several strategies such as sharing 
information to potential students using social media platform should be performed as a way of increasing the awareness of the courses offered. Apart from that, school visits and participation in educational fairs help to enhance awareness as well as provide an avenue for the students to discuss career opportunities.

The comparison of the mean score between males and females shows that females tend to pay more attention to these categories compared to their male counterparts. As previously mentioned, the cost is a critical factor because it is undeniable that students are cost-conscious. The results of the present study are consistent with the study of Baharun et al. (2011) which indicated that women tend to view safety as an important determinant factor of choice. On the other hand, men place more importance on sporting activities such as physical aspects, facilities, and resources. Regarding this matter, it is suggested for higher education institution operators to revise their educational fees regularly by offering courses at an affordable price. In other words, these elements must be kept in mind while addressing potential students, especially in the Orang Asli market.

\section{Conclusion}

In conclusion this research examines the factors influencing Orang Asli students intention to study at Malaysian public university. This research indicates cost of education, degree (content and structure), physical aspects, facilities and resources, the value of education, and course and career information; having significant impact on the students' choice in choosing which institution of higher learning to attend.

The present study successfully identified three most important factors among the students which are Physical Aspects and Facilities, Course and Career Information, and Degree (content and structure). On another note, the study found that female students emphasised their concern on the Cost of Education and Course and Career Information. The current research presented the importance of understanding the significant factors that are commonly considered by potential students in choosing a university to further their study. Therefore, different strategies must be developed to adhere to the needs of this particular market. Furthermore, UiTM is recommended to understand the needs of potential students and work on satisfying these needs to increase the numbers of university enrolment.

Moreover, universities specifically UiTM should note that all the attributes identified in the present study are considered important by the indigenous students. In other words, these attributes should be taken into consideration when targeting and promoting education services to them. The most important factors identified by the Orang Asli students are 'cleaned and safe environment', 'Information given on career opportunities', and 'Specialist programs/special track'.

The results of the present study should be helpful to public university administrators, marketers, and policymakers considering that all of the attributes identified in the current research are important to the Orang Asli students. Accordingly, these attributes should be taken into consideration when targeting and promoting services to Orang Asli in Malaysia. Overall, these are critical issues that must be highly considered by UiTM when promoting and marketing this program to create sustainable competitive advantages, as well as its social obligation in providing the opportunity to students to have better academic education that enhances 
Vol. 10, No. 2, 2021, E-ISSN: $2226-6348$ @ 2021 HRMARS

student's opportunity to get jobs and improve themselves in the means of improving their family economic positions.

\section{Suggestion for Future Research}

The generalisability of these findings is limited because the current research only investigated the intention of Orang Asli to study at a public university. Therefore, it is recommended for future works to integrate private institutions into the studies as well as expand the outcomes by including other statistical tests.

\section{References}

Abeygunawardena, K. V. (2018). Influential factors in selecting a bachelor's degree from international degree programmes offered in sri lanka: perspectives of lecturers and graduates. Proceedings of the International Conference on Education, 4(1), 51-61. https://doi.org/10.17501/icedu.2018.4106

Agrey, L., \& Lampadan, N. (2014). Determinant factors contributing to student choice in selecting a university. Journal of Education and Human Development, 3(2), 391-404.

Ancheh, K. S. B., Krishnan, A., \& Nurtjahja, O. (2007). Evaluative criteria for selection of private universities and colleges in Malaysia. Journal of International Management Studies, 2(1), 111.

Ariffin, K. H. K., Islam, A., \& Zaidi, N. I. B. M. (2014). Determinants students' selection of higher education institutions in Malaysia. Advances in Environmental Biology, 406-417.

Baharun, R., Awang, Z., \& Padlee, S. F. (2011). International students' choice criteria for selection of higher learning in Malaysian private universities. African Journal of Business Management, 5, 4704-4714.

Chapman, D. (1981). A model of student college choice. Journal of Higher Education, 52, 490505.

Chapman, R. (1984). Toward a theory of college choice: a model of college search and choice behaviour. Canada: University of Alberta Press.

Ciriaci, D., \& Muscio, A. (2011). University choice, research quality and graduates' employability: Evidence from Italian national survey data. Alma Laurea Working Papers, 49, 1-14.

Cubillo, J. M., Sánchez, J., \& Cerviňo, J. (2006). International Students' Decision-Making Process. International Journal of Educational Management. 20(2), 101-115.

Daily, C. M., Farewell, S., \& Kumar, G. (2010). Factors Influencing the University Selection of International Studies. Academy of Educational Leadership Journal. 14(3), 59-75.

Eidimtas, A., \& Juceviciene, P. (2014). Factors influencing school-leavers decision to enrol in higher education. Procedia-Social and Behavioral Sciences, 116, 3983-3988. doi: 10.1016/j.sbspro.2014.01.877

Fernandez, J. L. (2010). An exploratory study of factors influencing the decision of students to study at Universiti Sains Malaysia. Kajian Malaysia: Journal of Malaysian Studies, 28(2).

Holmegaard, H. T., Ulriksen, L. M., \& Madsen, L. M. (2014). The process of choosing what to study: A longitudinal study of upper secondary students' identity work when choosing higher education. Scandinavian Journal of Educational Research,58(1), 21-40. https://doi.org/10.1080/00313831.2012.696212 
Hossler, D. (1985). A research overview of student college choice", Association for the Study of Higher Education, Chicago, IL.

Hossler, D., Schmit, J., \& Vesper, N. (1999). Going to College: How Social, Economic, and Educational Factors Influence the Decisions Students Make. Johns Hopkins Press, Baltimore.

Hussin, N. L., Muhamad, N., \& Sukor, M. K. T. A. (2019). Determinants of students' choice of courses and university selection. Journal of Business Innovation, 4(2), 71.

Gibbons, S., \& Vignoles, A. (2009). Access, Choice and Participation in Higher Education. London, England: Centre for the Economics of Education, London School of Economics.

Griffin, A., \& Houser, J. (1993). The voice of the customer. Marketing Science, Winter, 1-27.

Ivy, J. (2010). Choosing Futures: Influence of Ethnic Origin in University Choice. International Journal of Educational Management. 24(5), 391-403.

Jackson, G. A. (1982). Public Efficiency and Private Choice in Higher Education. Education Evaluation and Policy Analysis. 4 (2), 237-247.

Jalaluddin, R. H., Megan, C., \& Fang, L. Y. (2019). A Study of Factors Influencing Students' Decision to Pursue to Tertiary Education. In Proceedings of the 2019 International Conference on Management Science and Industrial Engineering, pp134-138. https://doi.org/10.1145/3335550.3339902

Johnston, T. C. (2010). Who and What Influences Choice of University? Student and University Perceptions. American Journal of Business Education. 3(10), 15-23.

Joseph, M., \& Joseph, B. (1998) Identifying need of potential students in tertiary education for strategy development. Quality Assurance in Education, 6(2), 90-6.

Joseph, M., \& Joseph, B. (2000). Indonesian students' perceptions of choice criteria in the selection of a tertiary institution: strategic implications", International Journal of Educational Management, Vol. 14(1), 40-44. https://doi.org/10.1108/09513540010310396

Keskinen, E., Tiuraniemi, J., \& Liimola, A. (2008). University selection in Finland: How the decision is made. International Journal of Educational Management. 22(7), 638-650.

Koe, W. L. (2012). Factors Influencing the Foreign Undergraduates' Intention to Study at Graduate School of a Public University. Jurnal Kemanusiaan. Vo. 10(1). elSSN: 2600-7555.

Krone, F., Gilly, M., Zeithaml, V., \& Lamb, C. (1983). Factors influencing the graduate business school decision. American Marketing Association Educators' Proceedings. Chicago, IL.

Kusumawati, A., Yanamandram, V. K., \& Perera, N. (2010). Exploring student choice criteria for selecting an Indonesian public university: A Preliminary Finding. ANZMAC 2010 Doctoral Colloquium Christchurch, New Zealand: ANZMAC, 1-27.

Loren, A., \& Naltan, L. (2014). Determinant factors contributing to student choice in selecting a university. Journal of Education and Human Development, 3(2), 391-404.

Maguire, J., \& Lay, R. (1981). Modeling the college choice: image and decision. College and University, 56, 113-26.

Murphy, P. (1981). Consumer buying roles in college choice. College and University, 56, 140-50.

Mustafa, S. A. A., Sellami, A. L., Elmaghraby, E. A. A., \& Al-Qassass, H. B. (2018). Determinants of college and university choice for high-school students in Qatar. International Journal of Higher Education, 7(3). https://doi.org/10.5430/ijhe.v7n3p1 
O'Brien, A., Webb, P., Page, S., \& Proctor, T. (2007). A study into the factors influencing the choice-making process of Indian students when selecting an International University for Graduate Study Using Grounded Theory.

Oosterbeek H., Groot W., \& Hartog J. (1992) An empirical analysis of university choice and earnings. De Economist, 140, 293-309.

Padlee, S. F., Kamaruddin, A. R., \& Baharun, R. (2010). International students' choice behavior for higher education at Malaysian private universities. International Journal of Marketing Studies. 2(2), 202-211.

Pallant, J. (2005) SPSS Survival Manual. A Step by Step Guide to Data Analysis Using SPSS for Windows (version 12). Allen \& Unwin.

Piróg, D. (2017). Choosing Educational Services in Higher Education - a Theoretical Approach. Studies of the Industrial Geography Commission of the Polish Geographical Society, 31(3), 204-219. https://doi.org/10.24917/20801653.313.13

Rumana, L. A. (2019). Factors Affecting Bangladeshi Private University Students' Choice of Institutions for Undergraduate Study. Asian Journal of University Education, 15(2), 126-137.

Sewell, W. H., Shah, V. P. (1978). Social class, parental encouragement, and educational aspirations. Am J Sociol. 873, 559-572.

Sia, J. K. M. (2011). Post-secondary students' behaviour in the college choice decision. Journal of Marketing Research \& Case Studies, 2011, 1-15. DOI: 10.5171/2011.440964

Sia, J. (2013). University choice: Implications for marketing and positioning. Education, 3(1), 7-14. http://doi.org/10.5923/j.edu.20130301.02

Sidin, S. M., Hussin, S. R., \& Tan, H. S. (2003). An exploratory study of factors influencing the college choice decision of undergraduate students in Malaysia. Asia Pacific Management Review, 8(3).

Tang, T. L., Tang, D. S., Tang, C. S. (2004), College tuition and perceptions of private university quality, International Journal of Educational Management, 18, 304-316.

Tierney, M. (1983). Student college choice sets toward an empirical characterization. Research in Higher Education, 18, 27-81.

Tucciarone, K. (2008). Advertising's effect on community college search and choice. The Community College Enterprise, 73-91.

Vulperhorst, J. P., Van der Rijst, R. M., \& Akkerman, S. F. (2020). Dynamics in higher education choice: weighing one's multiple interests in light of available programmes. High Educ 79, 1001-1021. https://doi.org/10.1007/s10734-019-00452-x

Webb, M. (1993). Variables influencing graduate business students' college selections. College and University, 68(1), 38-46.

Yusuf, B. N. M., Ghazali, M. Q. M., \& Abdullah, M. F. S. (2017). Factors Influencing Local and International Students Decision in Choosing Public Higher Learning Institutions in Northern Region of Malaysia. International Journal of Social Sciences, 48(1), 29-41. 